Edisi Januari - Juni 2020 Vol 19 No 1

\section{JURNAL ILMU PEMERINTAHAN}

\section{nakhoda}

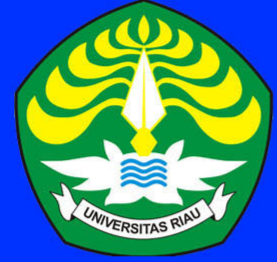

Innovation Hub: Media Kolaborasi Menuju Pemerintahan Daerah Inovatif Herie Saksono

Institusional Building dalam Mengatasi Persoalan Pertambangan Emas Tanpa Izin Di Kabupaten Kuantan Singingi Provinsi Riau

Khotami

Gerakan Masyarakat Tertib Administrasi Kependudukan Melalui Inovasi Pelayanan Lukadesi (Keluarga Berduka Desa Siaga)

Di Kabupaten Sleman D.I Yogyakarta

Hendy Setiawan, Fariza Ikhsanditya

Provinsi 'Istimewa Melayu Riau Kepulauan'

Muchid Albintani, Auradian Marta

Kaderisasi dan Penetapan Calon Legislatif pada Partai Politik (Studi DPD Partai Nasional Demokrat Seram Bagian Barat 2019)

Fandi Ahmad Sintani, Wahab Tuanaya, Marno Wance

Factors of Affect Deliberation of Maguwoharjo

Village Development Planing Sub-District Depok Regency Sleman Yogyakarta Muhammad Rafi, Ulung Pribadi, Fajar Rahmanto

Survey Kepuasan Masyarakat (SKM) pada Badan PendapatanDaerah Kabupaten Bintan

Suherry, Billy Jenawi, Rendra Setyadiharja,

Zamzami A Karim, Firman Setyawan, Rany Angraini

Peran Dewan Perwakilan Daerah (DPD) dalam

Pembentukan Daerah Otonomi Baru (DOB) Di wilayah Provinsi Maluku Utara

Abdul Halil Ibrahim, Bakri La Suhu, Rifjal Tifandy, Marno Wance

MEDIA INFORMASI DAN KOMUNIKASI ILMIAH CIVITAS AKADEMIKA JURUSAN ILMU PEMERINTAHAN

FAKULTAS ILMU SOSIAL DAN ILMU POLITIK

UNIVERSITAS RIAU
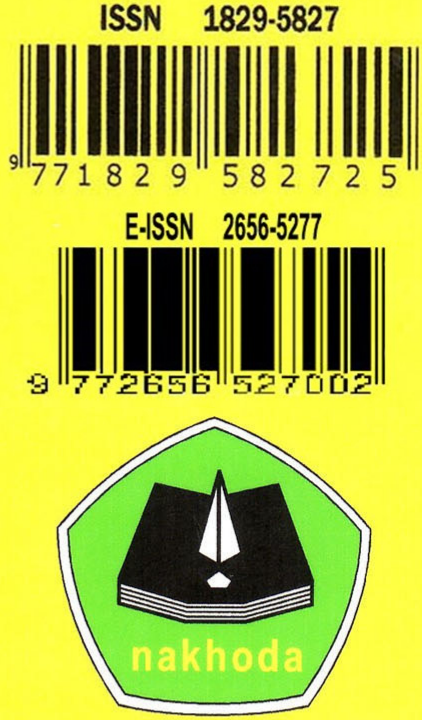

DITERBITKAN OLEH :

LABORATORIUM ILMU PEMERINTAHAN
SEKRETARIAT :

KAMPUS BINA WIDYA SIMPANG BARU

PANAM KM. 12,5 PEKANBARU

(28293) Telp/Fax. (0761)63277 
NAKHODA:

JURNAL

ILMU PEMERINTAHAN
NAKHODA: JURNAL ILMU PEMERINTAHAN

Edisi Januari - Juni 2020 Volume: 19 Nomor: 1

ISSN : 1829-5827 | E-ISSN : 2656-5277

DOI : https://doi.org/10.35967/jipn

https://nakhoda.ejournal.unri.ac.id/index.php/JIPN

INNOVATION HUB: MEDIA KOLABORASI MENUJU PEMERINTAHAN DAERAH INOVATIF

Herie Saksono

Badan Penelitian dan Pengembangan (BPP) Kementerian Dalam Negeri, Jakarta, Indonesia

$1-16$

INSTITUTION BUILDING DALAM MENGATASI PERSOALAN PERTAMBANGAN EMAS

TANPA IZIN DI KABUPATEN KUANTAN SINGINGI PROVINSI RIAU

Khotami

Program Studi Ilmu Pemerintahan, Fakultas IImu Sosial dan IImu Politik Universitas Islam Riau. 17 - 37

Pekanbaru-Indonesia

GERAKAN MASYARAKAT TERTIB ADMINISTRASI KEPENDUDUKAN MELALUI INOVASI

PELAYANAN LUKADESI (KELUARGA BERDUKA DESA SIAGA) DI KABUPATEN SLEMAN

D.I. YOGYAKARTA

Hendy Setiawan ${ }^{1}$, Fariza Ikhsanditya ${ }^{2}$

1,2 Departemen IImu Pemerintahan, Universitas Muhammadiyah Yogyakarta, Yogyakarta,

Indonesia

PROVINSI “ISTIMEWA MELAYU KEPULAUAN RIAU” (GAGASAN PERMULAAN)

Muchid Albintani', Auradian Marta ${ }^{2}$

1,2 Jurusan IImu Pemerintahan, Fakultas IImu Sosial dan IImu Politik, Universitas Riau

KADERISASI DAN PENETAPAN CALON LEGISLATIF PADA PARTAI POLITIK (Studi DPD

Partai Nasional Demokrat Seram Bagian Barat 2019

Fandi Ahmad Sintani ${ }^{1}$, Wahab Tuanaya ${ }^{2}$, Marno Wance ${ }^{3}$

1,2,3 Jurusan IImu Pemerintahan, Universitas Pattimura, Indonesia

$75-90$

FACTORS THAT AFFECT DELIBERATION OF MAGUWOHARJO VILLAGE DEVELOPMENT

PLANNING SUB-DISTRICT DEPOK REGENCY SLEMAN YOGYAKARTA

Muhammad Rafi ${ }^{1}$, Ulung Pribadi2, Fajar Rahmanto ${ }^{3}$

1,2,3 Department of Government Affairs and Administration, Universitas Muhammadiyah

Yogyakarta, Indonesia

SURVEY KEPUASAN MASYARAKAT (SKM) PADA BADAN PENDAPATAN DAERAH

KABUPATEN BINTAN

Suherry ${ }^{1}$, Billy Jenawi², Rendra Setyadihardja ${ }^{3}$, Zamzami A. Karim4,

Firman Setiawan ${ }^{5}$, Rany Angraini ${ }^{6}$

$102-112$

1,2,3,4 STISIPOL Raja Haji, Tanjungpinang, Indonesia

5,6 Bapelitbang, Bintan, Indonesia

PERAN DEWAN PERWAKILAN DAERAH (DPD) DALAM PEMBENTUKAN DAERAH

OTONOMI BARU (DOB) DI WILAYAH PROVINSI MALUKU UTARA

Abdulhalil Hi. Ibrahim ${ }^{1}$, Bakri La Suhu2, Rifjal Tifandy 3 Marno Wance 4

1,2,3 IImu Pemerintahan Universitas Muhammadiyah Maluku Utara, Kota Ternate, Indonesia

$113-127$

${ }^{4}$ IImu Pemerintahan, Universitas Pattimura, Kota Ambon, Indonesia 


\title{
PERAN DEWAN PERWAKILAN DAERAH (DPD) DALAM PEMBENTUKAN DAERAH OTONOMI BARU (DOB) DI WILAYAH PROVINSI MALUKU UTARA
}

\author{
Abdulhalil Hi. Ibrahim ${ }^{1}$, Bakri La Suhu ${ }^{2}$, Rifjal Tifandy ${ }^{3}$ Marno Wance $^{4}$ \\ 1,2,3 Ilmu Pemerintahan Universitas Muhammadiyah Maluku Utara, Kota Ternate, Indonesia \\ ${ }^{4}$ Ilmu Pemerintahan, Universitas Pattimura, Kota Ambon, Indonesia \\ chalilibrahim101@gmail.com,bakrilasuhu@yahoo.com,ipmummu@gmail.com
}

\begin{abstract}
ABSTRAK
Penelitian ini bertujuan untuk mengetahui Peran Dewan PerwakilanDaerah (DPD) dalam pembentukan DOB Kabupaten Galeda-Loloda. Menggunakan metode deskriptif kualitatif yaitu peneliti berusaha memberikan pemahaman secara mendalam tentang proses pemekaran daerah serta memberi gambaran yang jelas mengenai masalah yang berhubungan dengan penelitian.Sumber data yang digunakan yakni data primer dan data sekunder, teknik pengumpulan data melalui observasi, wawancara dan dokumen.Hasil temuan penelitian menunjukan bahwa DPD Provinsi Maluku Utara memiliki peran yang aktif dalam mendorong pembentukan DOB Galela-Loloda. Peran aktif yang dilakukan oleh DPD Provinsi Maluku Utara yakni (1) pada tahap awal pembentukan Galela-Loloda, peran DPD Provinsi Maluku Utara yaitu menerima semua aspirasi masyarakat Galela-Loloda, aktif menindaklanjuti sesuai dengan desain besar rencana pembangunan daerah otonomi baru yang dikeluarkan oleh pemerintah, (2) Pada tahap proses uji kelayakan Daerah Otonom Baru (DOB) Galela-Loloda, peran DPD RI Provinsi Maluku Utara yakni melakukan kunjungan kerja untuk melihat (a) Batas-batas wilayah Galela-Loloda, (b) Syarat fisik kewilayahan, (c) Jumlah penduduknya, dan (d) Potensi Daerah, dan (3) Tahap proses pembahasan di tingkat DPD RI dan DPR RI khususnya Komisi II, peran DPD RI Provinsi Maluku Utara yakni bersama-sama dengan DPD RI, $D P R$ RI yang berperan dalam membahasan undang-undang pemekaran bersama Pemerintah membahas DOB Galela-Loloda, menyampaikan semua hasil kajian yang telah dilakukan dan DPD RI Provinsi Maluku Utara menyatakan Galela-Loloda layak untuk dimekarkan menjadi Daerah Otonom Baru.
\end{abstract}

Kata Kunci: Daerah Otonomi Baru, Dewan Perwakilan Daerah, Proses Pembahasan

\section{PENDAHULUAN}

Kehadiran Dewan Perwakilan Daerah (DPD) pada dasarnya didasari oleh semua pihak baik Pemerintah pusat maupun daerah untuk memperbaiki hubungan kerja dan penyaluran kepentingan antara kedua level pemerintahan tersebut. Dalam hal ini, DPD juga diharapkan hadir sebagai lembaga yang mampu membantu memberikan masukan dan rekomendasi kepada DPR RI untuk mengatasi kesenjangan antara pusat dan daerah sesuai semangat otonomi daerah. Pemekaran daerah memberikan kebebasan bagi daerah untuk mengatur daerah sendiri dengan tujuan untuk dapat menjamin keadilan pemeratan pembanguan, ruang demokrasi bagi masyarakat turut berpartisipasi dalam ruang politik dan jaminan keutuhan integritas wilayah negara.

Salah satu tujuan pembentukan 


\author{
NAKHODA: JURNAL ILMU PEMERINTAHAN \\ Edisi Januari - Juni Tahun 2020 Volume: 19 Nomor: 1 \\ ISSN : 1829-5827 | E-ISSN : 2656-5277 \\ DOI : https://doi.org/10.35967/jipn \\ https://nakhoda.ejournal.unri.ac.id/index.php/JIPN
}

DPD adalah untuk dapat memperjuangkan aspirasi dari masyarakat serta dapat membawa konsep kepentingan daerah di pusat. Lembaga DPD sebagai representasi perwakilan legislatif yang independen dipandang para senator memiliki keberpihakan untuk dapat melakukan koreksi atau penyempurnaan sistem utusan daerah di MPR. Keikutsertaan daerah dalam utusan daerah di MPR sangat terbatas yaitu pada saat sidang-sidang MPR (selama Orde Baru, hanya dua kali dalam lima tahun). Partispasi aktif yang masih minim disebabkan ruang kewenangan yang belum diberikan kepada lembaga senator di pusat. Selama ini harapan pemerintah daerah terhadap DPD adalah memaksimalkan peran tersebut demi memajukan dan meningkatkan pelayanan terhadap masyarakat yang diwakilinya.

DPD merupakan lembaga yang merepresentasi perwakilan daerah di pusat yang mencalonkan diri secara perseorangan dan tidak terikat oleh kepentingan partai politik. Hubungannya untuk membawa kepentingan konstituen dengan lembaga-lembaga politik/pemerintahan di daerah tidak banyak diatur secara formal pada level strategis (UUD dan peraturan perundangundangan). Terkait pokok ini, UUD 1945 hanya mengatur ihwal pemilihan anggota DPD dari setiap provinsi melalui pemilu dan penjabaran tata cara pemilihannya. Namun kewenangan DPD untuk ikut terlibat bersama DPR RI dalam merumuskan dan menetapkan kebijakan publik masih setengah hati. Sementara UU No. 22/2003 mengatur segala ihwal tugas dan wewenang DPD terkait domain urusan/kepentingan daerah, namun tidak ada sifat pengaturan yang tegas terkait dengan kewajiban pelaksanaan dan sanksi bagi kegagalannya. Rumusan kewajiban anggota DPD yang terkait kepentingan daerah (seperti menyerap dan menindak lanjuti aspirasi daerah, memberikan pertanggungjawaban secara moral dan politis kepada pemilih dan daerah pemilihannya, dll) terkesan normatif, standar dan merupakan kewajiban umum yang juga terdapat pada lembaga negara lain semacam DPR. Pokok yang sedikit lebih tegas hanya terkait pemberhentian antar waktu anggota DPD, seperti keputusan pemberhentian oleh Badan Kehormatan DPD berdasarkan antara lain pengaduan oleh pemilih dari daerah asal anggota DPD bersangkutan (Pasal 88 ayat (4) yang disampaikan melalui DPRD Provinsi setempat untuk diteruskan kepada Badan Kehormatan DPD.

Dewan Perwakilan Daerah adalah merupakan representasi penduduk dalam suatu wilayah provinsi yang akan mewakili kepentingan-kepentingan daerah dalam proses pengambilan keputusan politik penting ditingkat nasional. Sebagai lembaga legislatif Dewan perwakilan Daerah (DPD) juga menjadi lembaga pengontrok kebijakan publik untuk dapat memastikan jalannya roda pemerintahan dengan baik dan sesuai aturan yang berlaku. Berdasarkan pada UU MD3 (Majelis Permusyawaratan Rakyat, Dewan Perwakilan Rakyat, Dewan Perwakilan Daerah, Dan Dewan Perwakilan Rakyat Daerah), mempunyai fungsi:

1. Pengajuan rancangan undang-undang yang berkaitan dengan otonomi daerah, hubungan pusat dan daerah, pembentukan dan pemekaran serta 


\author{
NAKHODA: JURNAL ILMU PEMERINTAHAN \\ Edisi Januari - Juni Tahun 2020 Volume: 19 Nomor: 1 \\ ISSN : 1829-5827 | E-ISSN : 2656-5277 \\ DOI : https://doi.org/10.35967/jipn \\ https://nakhoda.ejournal.unri.ac.id/index.php/JIPN
}

penggabungan daerah, pengelolaan sumber daya alam dan sumber daya ekonomi lainnya, serta yang berkaita ndengan perimbangan keuangan pusat dan daerah kepada DPR;

2. Ikut dalam pembahasan rancangan undang-undang yang berkaitan dengan otonomi daerah, hubungan pusat dan daerah, pembentukan, pemekaran dan penggabungan daerah, pengelolaan sumber daya alam dan sumber daya ekonomi lainnya, serta perimbangan keuangan pusat dan daerah;

3. Pemberian pertimbangan kepada DPR atas rancangan undang-undang tentang anggaran pendapatan dan belanja Negara dan rancangan undang-undang yang berkaitan dengan pajak, pendidikan, dan agama; serta

4. Pengawasan atas pelaksanaan undangundang mengenai otonomi daerah, pembentukan, pemekaran dan penggabungan daerah, hubungan pusat dan daerah, pengelolaan sumber daya alam dan sumber day aekonomi lainnya, pelaksanaan APBN, pajak, pendidikan, dan agama.

Pemekaran Wilayah pada dasarnya bertujuan untuk peningkatan pelayanan (service delivery) Pemerintah Daerah (local government) kepada masyarakat,agar lebih efisien dan efektif terhadap potensi, kebutuhan maupun karakteristik di masing-masing daerah. Dengan demikian adanya pemekaran wilayah seharusnya akan membuat suatu daerah menjadi semakin terbuka, jalur pengembangannya lebih luas, tersebar keseluruh wilayah (Tim analisis dan evaluasi hukum tentang pemekaran wilayah BPHN, 2009).
Gelombang pemekaran dan atau pembentukan otonom baru penyebabnya adalah letak geografis dan rentang kendali ibu kota kabupaten terhadap daerah lainnya, menjangkau dengan akses laut dan pulau yang membutuhkan biaya serta waktu untuk sampai di ibu kota Kabupaten. Keterbatasan jangkaun antara kabpaten dengan desa-desa lain diyakini jauh dari segala aspek pelayanan publik untuk masyarakat, memperpendek rentang kendali untuk pelayanan dan kesejahteraan masyarakat, serta pemerataan pembangunan.

Kesejahteraan masyarakat dan peningkatan pelayanan publik di daerah menjadi alasan utama sehingga daerah menuntut adanya pemekaran daerah otonom baru. Konteks Provinsi Maluku Utara, ada beberapa daerah telah menyuarakan pemekaran daerah, seperti diujung Selatan Halmahera yakni Pulau Obi. Tuntutan pemekaran Kabupaten Kepulauan Obi sudah di deklarasikan pada tanggal 20 Maret 2008 bersamaan dengan kegiatan Musabakah Tilawatil Qurean (MTQ) Tingkat Kabupaten Halmahera Selatan yang bertempat di Laiwui Kecamatan Pulau Obi. Deklarasi pemekaran kabupaten Kepulauan Obi mendapat respon dan disetujui oleh DPRD yang diwakili oleh Ketua DPRD (Bahrain Kasuba dari Partai PKS asal etnis Tobela) dan beberapa anggota DPRD yang berasal dari Kepulauan Obi yang etnisnya dari Suku Buton (La Jaya dari Partai Patriot, Idhar La Masa dari Partai Golkar, Hi Ibrahim dari Partai PBR, Rudi dari Partai PKB, Hi Amin dari Partai PKS, dan Rosihan dari Partai PKS), sementara pihak pemerintah dalam hal ini Bupati tidak 


\author{
NAKHODA: JURNAL ILMU PEMERINTAHAN \\ Edisi Januari - Juni Tahun 2020 Volume: 19 Nomor: 1 \\ ISSN : 1829-5827 | E-ISSN : 2656-5277 \\ DOI : https://doi.org/10.35967/jipn \\ https://nakhoda.ejournal.unri.ac.id/index.php/JIPN
}

ikutserta dalam deklarasi tersebut. (Bakri La Suhu dan Abdul Gaffar Karim, 2011).

Diujung Utara Halmahera yakni Galela-Loloda (GALDA) juga menyuarakan pemekaran daerah. Deklarasi pembentukan Daerah Otonom Baru (DOB) Galela-Loloda sudah dilakukan tanggal 12 Januari 2011 bertempat di lapangan Soakonora. Deklarasi juga di hadiri pihak pemerintah daerah Kabupaten Halmahera Utara dalam hal ini Bupati, dan sejumlah stakeholders; KNPI Halmahera Utara dan Asosiasi Mahasiswa Pemuda Pelajar Tobelo, Galela, Malifut, Loloda dan Kao (AMPP Togamaloka). Proses pembentukan/pemekaran Galela-Loloda tidak lepas dari adanya keterlibatan dari berbagai pihak baik itu seluruh masyarakat Galela-Loloda, elite lokal, unsur pemerintah daerah Kabupaten Halmahera Utara, DPRD Kabupaten Halmahera Utara, unsur pemerintah Provinsi Maluku Utara, DPRD Provinsi Maluku Utara dan Dewan Perwakilan Daerah (DPD) untuk wilayah Maluku Utara.

DPD memiliki peran dalam hal kewenangan legislasi (mengajukan Rancangan Undang-Undang, membahas RUU bersama DPR), kewenangan pertimbangan (memberi pertimbangan terhadap suatu RUU, pertimbangan pemilihan anggota BPK), dan kewenangan melakukan pengawasan (mengawasi pelaksanaan UU dimaksud). Sebagai lembaga perwakilan daerah DPD memiliki peran yang sangat penting dalam memperjuangkan aspirasi masyarakat yang ada di daerah, khususnya mengenai pemekaran daerah karena pemekaran pemerintahan daerah bisa bermanfaat terhadap percepatan pembangunan daerah dan pedekatan pelayanan kepada masyarakat, secara berjenjang. Hal ini berdampak kepada peningkatan kesejahteraan masyarakat yang menjadi tujuan pembangunan secara nasional.

\section{KERANGKA TEORI}

\section{Konsep Peran}

Peranan berasal dari kata peran, berarti sesuatu yang menjadi bagian atau memegang pimpinan yang terutama. Peranan menurut Levinson sebagaimana dikutip oleh Soekanto (1982), sebagai berikut: Peranan adalah suatu konsep prihal apa yang dapat dilakukan individu yang penting bagi struktur sosial masyarakat, peranan meliputi norma norma yang dikembangkan dengan posisi atau temp t seseorang dalam masyarakat, peranan dalam arti ini merupakan rang kaian peraturan-peraturan yang membimbing seseorang dalam kehidupan kemasyarakatani. Peranan memiliki tugas dan fungsi dalam melakukan hak serta kewajibannya sesuai dengan kedudukannya maka dia menjalankan suatu peranan. Perbedaan kedudukan dan peranan adalah sistem kerja organisasi sesuai dengan keududukan dan peranannya dalam mengelola sesuai dengan aturan yang berlaku. Keudukan peran sangat strategis sehingga tak ada peranan tanpa kedudukan atau kedudukan tanpa peranan. Sebagaimana halnya dengan kedudukan, peranan juga mempunyai arti. Setiap orang mempunyai macam-macam peranan yang berasal dari pola-pola pergaulan hidupnya (Ralph Linton dalam Soerjono Soekanto, 2001). 


\author{
NAKHODA: JURNAL ILMU PEMERINTAHAN \\ Edisi Januari - Juni Tahun 2020 Volume: 19 Nomor: 1 \\ ISSN : 1829-5827 | E-ISSN : 2656-5277 \\ DOI : https://doi.org/10.35967/jipn \\ https://nakhoda.ejournal.unri.ac.id/index.php/JIPN
}

Peranan yang melekat pada diri seseorang harus dibedakan dengan posisi dalam pergaulan kemasyarakatan. Posisi seseorang dalam masyarakat merupakan unsur statis yang menunjukan tempat individu pada organisasi masyarakat. Peranan lebih banyak menunjuk pada fungsi, penyesuaian diri dan sebagai suatu proses. Jadi, seseorang menduduki suatu posisi dalam masyarakat serta menjalankan suatu peranan. Menurut Levinson dalam Soerjono Soekanto (2001 : 269) menyatakan bahwa peranan mencakup tiga:

a. Peranan meliputi norma-norma yang dihubungkan dengan posisi atau tempat seseorang dalam masyarakat. Peranan dalam arti ini merupakan rangkaian peraturan-peraturan yang membimbing seseorang dalam kehidupan kemasyarakatan,

b. Peranan adalah suatu konsep tentang apa yang dapat dilakukan oleh individu dalam masyarakat sebagai organisasi, dan

c. Peranan juga dapat dikatakan sebagai perilaku individu yang penting bagi struktur sosial masyarakat

\section{Konsep Dewan Perwakilan Daerah}

Pembentukan Dewan Perwakilan

Daerah (DPD) dilakukan melalui perubahan ketiga UUD 1945 pada bulan November 2001. Dengan dibentuknya satu lagi lembaga tinggi negara ini (DPD), berarti sistem perwakilan dan parlemen berubah dari sistem satu kamar (unikameral) menjadi dua kamar (bikameral). Juga dengan dibentuknya lembaga ini, berarti Indonesia mengawali babak baru demokratisasi (Huda, Ni'matul, 2005).

Dewan Perwakilan Daerah (DPD) RI merupakan salah satu perwujudan tuntutan reformasi yang pembentukannya di wadahi dalam Perubahan Ketiga UUD 1945 oleh MPR pada tahun 2001. Selain itu juga, Dewan Perwakilan Daerah (DPD) merupakan lembaga perwakilan daerah yang berkedudukan sebagai lembaga negara. DPD terdiri atas wakil daerah provinsi yang dipilih melalui pemilihan umum.

Mengenai Dewan Perwakilan Daerah, yang menjadi gagasan dasar pembentukannya adalah keinginan untuk lebih mengakomodasi aspirasi daerah dan sekaligus memberi peran yang lebih besar kepada daerah dalam proses pengambilan keputusan politik untuk soal-soal yang berkaitan dengan daerah. Ketentuan BAB VII-A Pasal 22-C dan 22-D dalam UUD 1945 yang mengatur keberadaan DPD dalam struktur ketatanegaraan Indonesia antara lain dimaksudkan untuk :

a. Memperkuat ikatan daerah-daerah dalam wadah NKRI dan pemperteguh persatuan kebangsaan seluruh daerah;

b. Meningkatkan agregasi dan akomodasi aspirasi dan kepentingan daerahdaerah dalam perumusan kebijakan nasional bekaitan dengan Negara dan daerahdaerah;

c. Mendorong percepatan demokrasi, pembangunan dan kemajuan daerah secara serasi dan seimbang (Ni'matul Huda, 2005).

Dalam UU MD3 Pasal 249 menyatakan bahwa Dewan Perwakilan Daerah (DPD) mempunyai wewenang dan tugas : 


\author{
NAKHODA: JURNAL ILMU PEMERINTAHAN \\ Edisi Januari - Juni Tahun 2020 Volume: 19 Nomor: 1 \\ ISSN : 1829-5827 | E-ISSN : 2656-5277 \\ DOI : https://doi.org/10.35967/jipn \\ https://nakhoda.ejournal.unri.ac.id/index.php/JIPN
}

a. Mengajukan rancangan undang-undang yang berkaitan dengan otonomi daerah, hubungan pusat dan daerah, pembentukan dan pemekaran serta penggabungan daerah, pengelolaan sumber daya alam dan sumber daya ekonomi lainnya, serta yang berkaitan dengan perimbangan keuangan pusat dan daerah kepada DPR;

b. Ikut membahas rancangan undangundang yang berkaitan dengan hal sebagaimana dimaksud dalam huruf a; dan

c. Menyusun dan menyampaikan daftar inventaris masalah rancangan undangundang yang berasal dari DPR atau Presiden yang berkaitan dengan hal sebagaimana dimaksud dalam huruf a;

\section{Pengertian Pembentukan Daerah}

Dalam Undang-undang pengertian Pembentukan daerah adalah berupa penggabungan beberapa daerah atau bagian daerah yang bersandingan atau pemekaran dari satu daerah menjadi dua daerah atau lebih. Dalam hubungannya dengan pembentukan daerah/wilanyah otonomi, pasal 18 UUD 1945 antara lain menyatakan bahwa pembagian daerah Indonesia atas daerah besar dan daerah kecil, dengan bentuk dan susunan pemerintahannya yang ditetapkan oleh Undang-Undang. Daerah Indonesia akan dibagi menjadi daerah provinsi dan daerah provinsi akan dibagi menjadi daerah kabupaten dan daerah kota untuk mendukung pelaksanaan otonomi daerah ( $\mathrm{J}$ Kaloh, 2007).

Pembentukan Daerah menjadi daerah otonom baru selalu ditandai dengan pengembangan kawasan wilayah dalam upaya untuk mencapai pemerataan pembangunan demi mempercepat perwujudan kesejahteraan masyarakat Daerah. Pembentukan Daerah adalah merupakan tuntutan masyarakat yang berada di daerah, yang merasa kurangnya pembangunan infrastruktur Pemerintah Daerah dan pelayanan terhadap warganya.

Peraturan Pemerintah Nomor 78 tahun 2007 menyebutkan bahwa Pembentukan Daerah adalah pemecahan Kabupaten atau Kabupaten/Kota menjadi dua Daerah atau lebih.Menurut penulis Pembentukan adalah sebuah pelebaran, perluasan, atau penambahan wilanyah baru dalam suatu kawasan akibat percepatan pertumbahan masyarakat serta tuntutan kebutuhan pelanyanan akan segalah bidang yang seimbang dan dinamis bagi pertumbuhan sebuah Daerah yang mengarah pada ruang-ruang kawasan baru sebagai zona pelanyanan pemerataan kebutuhan masyarakat.

Persyaratan Pembentukan Daerah Otonom Baru (DOB), secara normatif telah diatur dalam Peratura Pemerintah (PP) Nomor 78 Tahun 2007 Tentang Tata Cara Pembentukan, Penghapusan, dan Penggabungan Daerah yang meliputi syarat administratif, teknis, dan fisik kewilayahan. Persyaratan administratif pembentukan daerah kabupaten/kota meliputi:

a. Keputusan DPRD kabupaten/kota induk tentang persetujuan pembentukan calon kabupaten/kota;

b. Keputusan bupati/walikota induk tentang persetujuan pembentukan calon kabupaten/kota;

c. Keputusan DPRD provinsi tentang persetujuan pembentukan calon kabupaten/kota; 


\author{
NAKHODA: JURNAL ILMU PEMERINTAHAN \\ Edisi Januari - Juni Tahun 2020 Volume: 19 Nomor: 1 \\ ISSN : 1829-5827 | E-ISSN : 2656-5277 \\ DOI : https://doi.org/10.35967/jipn \\ https://nakhoda.ejournal.unri.ac.id/index.php/JIPN
}

d. Keputusan gubernur tentang persetujuan pembentukan calon kabupaten/kota; dan e. Rekomendasi Menteri.

Keputusan DPRD kabupaten/kota diproses berdasarkan aspirasi sebagian besar masyarakat setempat. Dan keputusan DPRD provinsi berdasarkan aspirasi sebagian besar masyarakat setempat yang dituangkan dalam keputusan DPRD kabupaten/kota yang akan menjadi cakupan wilayah calon provinsi.

$$
\text { Persyaratan secara teknis }
$$
didasarkan pada faktor kemampuan ekonomi, potensi daerah, sosial budaya, sosial politik, kependudukan, luas daerah, pertahanan, keamanan, dan faktor lain yang memungkinkan terselenggaranya otonomi daerah. Adapun faktor lain tersebut meliputi pertimbangan kemampuan keuangan, tingkat kesejahteraan masyarakat, dan rentang kendali penyelenggaraan pemerintahan. Faktor sebagaimana dimaksud, dinilai berdasarkan hasil kajian daerah terhadap indikator sebagaimana tercantum dalam lampiran yang merupakan bagian yang tidak terpisahkan dari Peraturan Pemerintah ini.Suatu calon daerah otonom direkomendasikan menjadi daerah otonom baru apabila calon daerah otonom dan daerah induknya mempunyai total nilai seluruh indikator dan perolehan nilai indikator faktor kependudukan, faktor kemampuan ekonomi, faktor potensi daerah dan faktor kemampuan keuangan dengan kategori sangat mampu atau mampu.

Syarat fisik kewilayahan meliputi cakupan wilayah, lokasi calon ibukota, sarana dan prasarana pemerintahan. Cakupan wilayah untuk: pembentukan provinsi paling sedikit 5 (lima) kabupaten/kota; kabupaten paling sedikit 5 (lima) kecamatan; dan kota paling sedikit 4 (empat) kecamatan.

Dengan persyaratan dimaksud diharapkan agar daerah yang baru dibentuk dapat tumbuh, berkembang dan mampu menyelenggarakan otonomi daerah dalam rangka meningkatkan pelayanan publik yang optimal guna mempercepat terwujudnya kesejahteraan masyarakat dan dalam memperkokoh keutuhan Negara Kesatuan Republik Indonesia. Dalam pembentukan daerah, tidak boleh mengakibatkan daerah induk menjadi tidak mampu menyelenggarakan otonomi daerah, sehingga tujuan pembentukan daerah dapat terwujud dengan dilengkapi dengan kajian daerah.

\section{METODE PENELITIAN}

\section{a. Tipe dan Jenis Penelitian}

Tipe penelitian adalah kualitatif yaitu calon peneliti berusaha memberikan pemahaman secara mendalam tentang obyek yang di teliti serta memberi gambaran yang jelas mengenai masalah yang berhubungan dengan penelitian, sedangkan jenis penelitian adalah deskriptif kualitatif yakni peneliti berusaha memberikan gambaran secara umum mengenai masalah-masalah yang di teliti.

\section{b. Sumber Data}

1. Data Primer yaitu data yang diperoleh dari wawancara langsung peneliti, antara lain : Drs Abdurrahman Lahabato, Stevi Pasemanyeku dan Basri Salama.

2. Data Sekunder yaitu data yang diperoleh dari instansi yang ada pada Kantor DPD Provinsi Maluku Utara 
yang ada hubungan dengan proses penelitian.

c. Teknik Pengumpulan Data

Dengan bersandarkan pada pendekatan penelitian kualitatif, maka didalam tahap pengumpulan data digunakan adalah :

1. Observasi, yakni pengamatan yang sistematis terhadap gejala-gejala yang diteliti dengan cara terlangsung pada objek penelitian (Husaini Usman, 1995).

2. Wawancara, adalah percakapan dengan maksud tertentu. Percakapan itu dilakukan oleh dua pihak, yaitu yang mengajukan pertanyaan dan yang memberikan jawaban atas pertanyaan itu.

3. Dokumentasi, yakni pengumpulan data dengan cara mencatat atau mengutip dari dokumen atau arsiparsip yang diperlukan untuk melengkapi data primer yang diperoleh langsung dari responden.

\section{d. Teknik Analisa Data}

1. Reduksi data dengan cara membuat abstraksi dengan maksud untuk membuat rangkuman yang inti menyeleksi data sehingga data didapat sesuai dengan permasalahan yang diteliti.

2. Menyajikan data dalam bentuk yang sederhana yang sesuai dengan kriteria dan klasifikasi data yang sesuai dengan rumusan masalah dalam penelitian ini sehingga akan lebih mudah dipahami.

3. Mengumpulkan data-data yang telah didapat dari seluruh proses penelitian sehingga memudahkan penulis untuk membuat pemaknaan penuturan yang dapat dimengerti berkenaan dengan masalah yang diteliti (Lexy J. Moleong. 2006).

\section{HASIL DAN PEMBAHASAN}

\section{Prosedur Pembentukan Daerah Otonom Baru}

Inisiatif Pembentukan daerah otonom baru pada dasarnya berangkat dari adanya peluang hukum bagi masyarakat dan Daerah untuk melakukan Pembentukan/penggabungan daerah otonom sebagaimana tertuang dalam Peratura Pemerintah (PP) Nomor 78 Tahun 2007 Tentang Tata Cara Pembentukan, Penghapusan, dan Penggabungan Daerah. 


\section{Gambar 1. \\ Proses Pengusulan Wilayah Pembentukan di Tingkat Daerah}

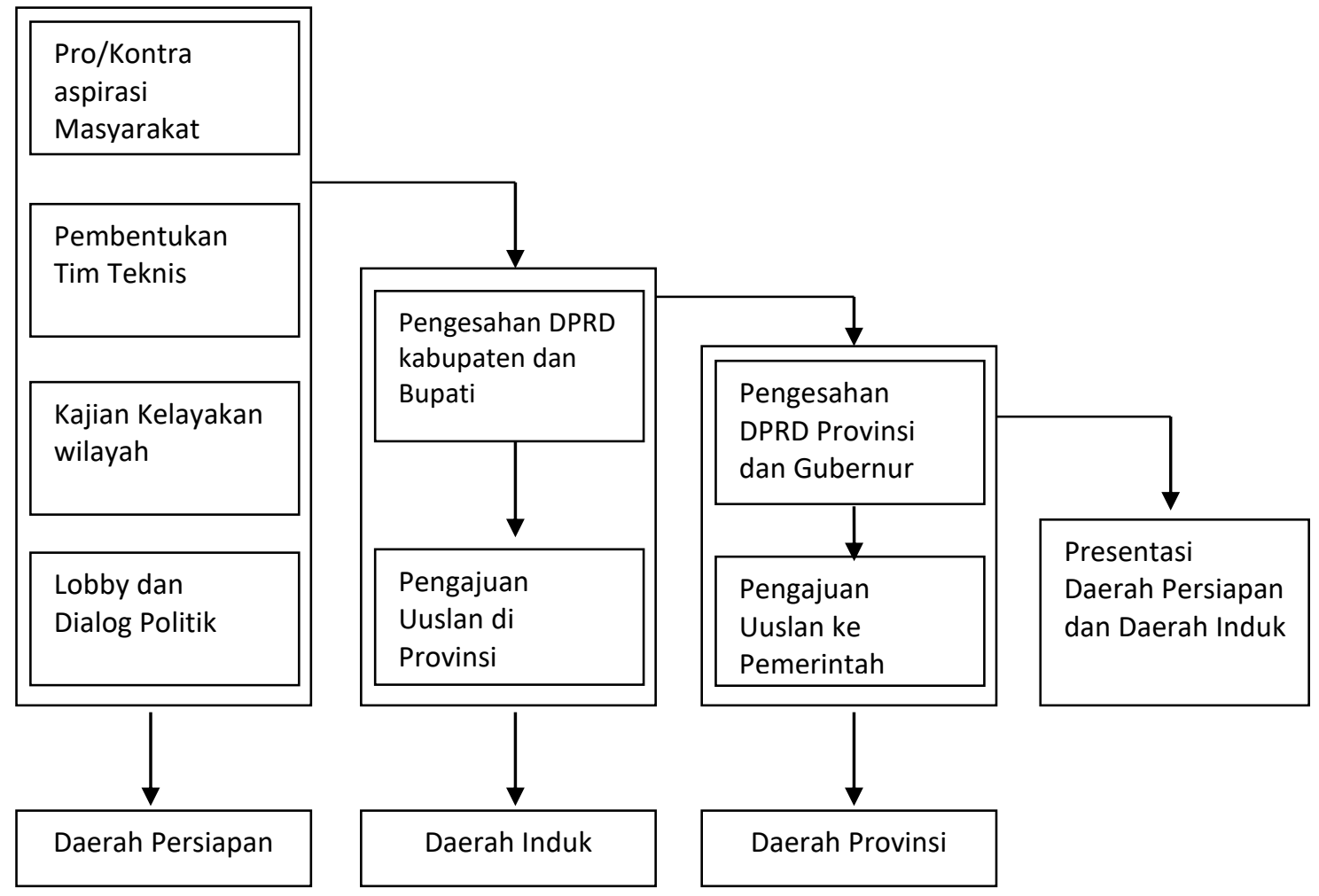

Dari gambar di atas, dijelaskan bahwa persiapan dalam Pembentukan wilayah dimulai dari wilayah yang mengusulkan. Usulan-usulan tersebut berbentuk proposal yang sudah memiliki pertimbangan-pertimbangan di dalamnya dan kajian-kajian ilmiah, sehingga ketika proposal rencana Pembentukan wilayah tersebut diajukan ke DPRD kabupaten/ kota dan kemudian ke propinsi, dapat dipertanggungjawabkan dengan berlandaskan peraturan-peraturan yang berlaku.

Peraturan pemerintah tersebut kemudian mengemukakan bahwa kebersyaratan untuk membentuk daerah otonom baru harus meliputi Syarat administrasi, teknis, dan fisik kewilayahan. Persyaratan administratif pembentukan daerah kabupaten/kota untuk kabupaten meliputi :

a. Keputusan DPRD kabupaten/kota induk tentang persetujuan pembentukan calon kabupaten/kota;

b. Keputusan bupati/walikota induk tentang persetujuan pembentukan calon kabupaten/kota;

c. Keputusan DPRD provinsi tentang persejutuan pembentukan calon kabupaten/kota; 


\author{
NAKHODA: JURNAL ILMU PEMERINTAHAN \\ Edisi Januari - Juni Tahun 2020 Volume: 19 Nomor: 1 \\ ISSN : 1829-5827 | E-ISSN : 2656-5277 \\ DOI : https://doi.org/10.35967/jipn \\ https://nakhoda.ejournal.unri.ac.id/index.php/JIPN
}

d. Keputusan Gubernur tentang persetujuan pembentukan calon kabupaten/kota; dan

e. Rekomendasi Menteri.

Keputusan DPRD Kabupaten/Kota diproses berdasarkan aspirasi sebagian besar masyarakat setempat. Dan keputusan DPRD provinsi berdasarkan aspirasi sebagian besar masyarakat setempat yang dituangkan dalam keputusan DPRD kabupaten/kota yang akan menjadi cakupan wilayah calon provinsi.

Pembentukan Kabupaten GalelaLoloda untuk syarat administratif sesuai dengan ketentuan PP No. 78 tahun 2007, dimana harus ada Keputusan Badan Permusyarawatan Desa (BPD) seKecamatan Galela, Galela Utara, Galela Barat, Galela Selatan, Loloda Kepulauan, dan Kecamatan Loloda Utara. Selain keputusan BPD se-kecamatan, ada juga Keputusan DPRD Kabupaten Halmahera Utara Nomor:04/KPTS/DPRDHALUT/2011 tentang Persetujuan Pembentukan Galela-Loloda dan Kao Raya Di Kabupaten Halmahera Utara Provinsi Maluku Utara, dan Keputusan DPRD Provinsi Maluku Utara Tentang Persetujuan Pembentukan Kabupaten Galela-Loloda yang tertuang dalam Keputusan Nomor:16/KPTS/DPRDMU/2012 tentang Persetujuan Terhadap Usulan Pembentukan Kabupaten GalelaLoloda.

Syarat fisik kewilayahan meliputi cakupan wilayah, lokasi calon Ibukota, sarana dan prasana pemerintahan. Cakupan wilayah untuk pembentukan provinsi paling sedikit 5 (lima) Kabupaten; cakupan wilayah untuk pembentukan kabupaten paling sedikit 5 (lima) kecamatan; dan kota paling sedikit 4 (empat) kecamatan. Persyaratan secara fisik kewilayahan, maka Pembentukan Kabupaten Galela-Loloda sudah sesuai ketentuan PP No. 78 tahun 2007, dimana terdapat 6 (enam) kecamatan, yaitu terdiri dari :

1. Kecamatan Galela,

2. Kecamatan Galela Utara,

3. Kecamatan Galela Barat,

4. Kecamatan Galela Selatan,

5. Kecamatan Loloda Kepulauan, dan

6. Kecamatan Loloda Utara Berdasarkan

syarat-syarat pembentukan daerah otonom baru (DOB) sebagaimana yanga tertuang dalam Peraturan Pemerintah Nomor 78 tahun 2007 tentang Tata cara pembentukan, penghapusan, dan Penggabungan daerah, maka untuk syarat pembentukan DOB Galela-Loloda sudah memenuhi persyaratan untuk dapat diajukan kepada Pemerintah Pusat yang kemudian dapat dijadikan bahan kajian untuk dapat dimekarkan menjadi Daerah Otonom Baru. Memperhatikan syarat pembentukan daerah yang diatur dalam Peraturan Pemerintah tersebut tampaknya sangat ketat dan sulit untuk dipenuhi. Namun menurut effendy kenyataan proses teknokratis-administratifnya bisa sangat fleksibel. Kriteria kelayakan pembentukan mudah dipenuhi bahkan dimanipulasi (seperti kriteria jumlah penduduk yang tidak wajib" karena diakumulasikan dengan indikator lain ), maupun standar nilai meminimal kelulusan yang dapat dirasionalisasikan. Studi kelayakan yang dilakukan oleh pihak ketiga yang cenderung mendukung dan memaksa terjadinya pembentukan DOB.

Dalam pembahasannya melalui proses politik yang cenderung anarkis. 


\author{
NAKHODA: JURNAL ILMU PEMERINTAHAN \\ Edisi Januari - Juni Tahun 2020 Volume: 19 Nomor: 1 \\ ISSN : 1829-5827 | E-ISSN : 2656-5277 \\ DOI : https://doi.org/10.35967/jipn \\ https://nakhoda.ejournal.unri.ac.id/index.php/JIPN
}

Dalam implementasinya, proses pembentukan wilayah dapat dilakukan melalui dua pintu, yakni lewat lembaga politik (DPR) sebagai usulan inisiatif DPR, dan melalui institusi pemerintahan (Dewan Pertimbangan Otonomi Daerah/DPOD Depdagri). Argumenargumen politik sering kali memiliki posisi tawar yang lebih kuat dibandingkan dengan eksekutif dalam hal penolakan proposal pembentukan daerah baru.

Pandangan prasojo, bahwa tampaknya DPR dan pemerintah tidak memiliki nilai dasar dan tujuan akhir yang sama terhadap pembentukan daerah. Sejauh ini pembentukan daerah baru selalu berada dalam ruang politik semata. Nilai dasar dan tujuan pembentukan daerah otonom pada hakekatnya bisa berada secara kontinum antara demokrasi lokal dan efesiensi-efektivitas pemerintah.

Prasojo (2008) mengungkapkan bahwa penentuan batas kaitanya dengan daerah otonom harus mendasarkan pada pertimbangan efesiensi ekonomi dan efektivitas demokrasi. Kombinasi diantara keduanya mempunyai arti penting untuk menciptakan stabilitas dan fleksibility dan responsiveness. Mengingat bahwa berkaitan dengan daerah otonom, penentuan batas dan besaran daerah otonom merupakan hal yang krusial.

\section{Peran Dewan Perwakilan Daerah (DPD) Provinsi Maluku Utara dalam Pembentukan Daerah Otonom Baru Galela-Loloda}

Pemberian ruang partisipasi daerah dalam penyelenggaraan negara secara nasional untuk bersama-sama menentukan kebijakan nasional tidak memiliki makna ketika jembatan penghubung antara daerah dan pusat, terutama yang berpusat di parlemen hanya sebagai hiasan pelembagaan saja. Alasanya posisi DPD sebagai subordinated DPR (Efriza dan Syafuan Rosi, 2010). Sehingga menjadikan lembaga ini tidak dapat memperjuangka kepentingan dari daerah yang mereka wakili. Secara politik, DPD sebagai lembaga tinggi belum mampu menunjukan taring politiknya untuk lebih menunjukan eksistensi dan kinerja yang efektif dalam sistem parlemen di Indonesia. Sebab, peran DPD dalam menjalankan fungsi legislasinya, tidak diikuti dengan pemberian kekuasaan dan kewenangan yang memadai. Adapun diketahui kekuasaan dan kewenangan yang diberikan kepada DPD dalam membuat UU terbatas, itu pun tidak ada jaminan apakah disetujui oleh DPR. Sedangkan untuk masalah lainya, dalam hal perimbangan dan pengawasan, juga tanpa ada jaminan akan di terima oleh DPR. Dalam keadaan seperti ini, akan sulit bagi DPD untuk memainkan fungsi sebagai parlemen yang kedua, karena memang kewenangannya terbatas.

Proses pengusulan daerah otonom baru (DOB) sebenarnya telah menjadikan DPR dan pemerintah "tersandera" dalam tuntutan DOB. Kepentingan memperluas struktur dan posisi didaerah, tuntutan mengalirkan dana pusat ke daerah, janji kampanye pemilu, serta indikasi transaksi ekonomi politik memaksa dan menyandera anggota-anggota DPR untuk terus memberikan tempat bagi usulan dan inisiatif Pembentukan daerah. Rasanya sulit untuk dihentikan arus tuntutan pembentukan daerah otonom kalau hanya mengandalkan syarat-syarat teknisadministratif. Penyanderaan bukan hanya dilakukan calon DOB terhadap anggota- 


\author{
NAKHODA: JURNAL ILMU PEMERINTAHAN \\ Edisi Januari - Juni Tahun 2020 Volume: 19 Nomor: 1 \\ ISSN : 1829-5827 | E-ISSN : 2656-5277 \\ DOI : https://doi.org/10.35967/jipn \\ https://nakhoda.ejournal.unri.ac.id/index.php/JIPN
}

anggota DPR, tapi juga dilakukna DPR terhadap pemerintah.

Berbagai kepentingan ekonomipolitik di DPR sering sangat menyulitkan pemerintah untuk menahan RUU atas prakarsa (inisiatif) DPR. Pada akhirnya, ukuran-ukuran teknis, administrasi, dan fisik kewilayahan sebagaiman tertuang dalam PP No. 78 tahun 2007 terkalahkan oleh kepentingan dan keputusan politik. Dengan kata lain, bahwa tujuan pembentukan daerah untuk memakmurkan dan mensejahterakan rakyatnya tergantikan oleh kepentingan elite politik, baik di pusat maupun didaerah.

Dari sisi Pemerintah pusat, proses pembahasan Pembentukan wilayah yang datang dari berbagai Daerah melalui dua tahapan besar yaitu proses teknokratis (kajian kelayakan teknis dan administratif), serta proses politik karena selain harus memenuhi persyaratan teknokratis yang telah diatur dalam UU dan Peraturan Pemerintah, proposal Pembentukan harus didukung secara politis oleh DPR. Namun, dalam implementasinya ternyata faktor politik menjadi dominan. Kajian daerah yang dibuat terkadang merupakan kesepakan elite-elite lokal yang berkepentingan. Sehingga terjadi ketidakakuratan data, analisis dan argumen sangat lemah dan berbagai aspek lain yang tidak tepat. Anehnya usulan pemekaran daerah dengan dokumen pendukung yang sangat lemah dan amburadul pun ternyata tetap di terima pemerintah pusat dan dibahas di DPR sehingga lahirlah Undang-Undang Pembentukan Daerah.

Hasil penelitian dilakukan Bakri La Suhu dan Abdul Gaffar Karim (2011), menunjukkan bahwa pemekaran Kabupaten Kepulauan Obi di dorong oleh aspek geografis. Rencana pemekaran Kabupaten Kepulauan Obi menimbulkan pro dan kontra antara elit Obi dan elit yang ada di luar pulau Obi. Elit yang kontra pemekaran yaitu Bupati Halmahera Selatan (Muhammad Kasuba), karena Bupati memiliki kepentingan ekonomi (usaha bisnis) di wilayah Pulau Obi. Persaingan kepentingan terjadi dikalangan kelompok pro pemekaran antara elit di Pulau Obi dengan elit di wilayah Ternate, persaingan diantara pro pemekaran pada dasarnya adalah berebut pengaruh dan dukungan dari masyarakat Obi, dan upaya untuk mempertahankan dan/atau memperebutkan resource di wilayah Kepulauan Obi pasca pemekaran menjadi faktor persaingan kepentingan elit-elit pro pemekaran. Konspirasi terjadi karena kepentingan ekonomi antara elit pro pemekaran (Abu Karim La Tara, S.IP dan Hi. Subur) dengan elit kontra pemekaran (Bupati Muhammad Kasuba), konspirasi ini dalam rangka untuk mempertahankan dan mengamankan usaha bisnis (kepentingan ekonomi) di wilayah Kepulauan Obi. Sedangkan konfigurasi elit ternyata terjadi perpaduan antara aspek etnisitas dan aspek agama, sementara pada aspek geografis terjadi polaritas di antara elit-elit Obi. Terpolariasinya elit-elit Obi berdasarkan wilayah baik itu di wilayah Kepulauan Obi, Labuha-Bacan, dan di Ternate, menimbulkan persaingan kepentingan diantara masing-masing elit Obi yang ada di Provinsi Maluku Utara.

Tentu ini karena dalam proses pemekaran daerah, terjadi gesekan kepentingan kepentingan politik yang sulit dihindari. Proses pengusulan daerah baru lebih banyak terjadi secara ekstra parlementer. Kekuatan penting yang 


\author{
NAKHODA: JURNAL ILMU PEMERINTAHAN \\ Edisi Januari - Juni Tahun 2020 Volume: 19 Nomor: 1 \\ ISSN : 1829-5827 | E-ISSN : 2656-5277 \\ DOI : https://doi.org/10.35967/jipn \\ https://nakhoda.ejournal.unri.ac.id/index.php/JIPN
}

seringkali menjadi andalan para pengusul dari daerah adalah lobi. Masyarakat suatu daerah yang diwakili para tokohnya rela mengumpulkan uang belasan miliyar rupiah dari berbagai sumber untuk sekadar membeli Undang-Undang Pembentukan Daerah. Tentu saja bukan UU-nya yang mahal, tetapi proses sampai ke UU itulah yang harus diperjuangkan dengan susah payah dan biaya mahal. Padahal, dalam peraturan perundang-undangan menjelaskan bahwa tujuan pemekaran daerah senantiasa diarahkan untuk meningkatkan kesejahteraan masyarakat melalui:

1) peningkatan pelayanan kepada masyarakat;

2) percepatan pertumbuhan kehidupan masyarakat;

3) percepatan pelaksanaan pembangunan perekonomian daerah;

4) percepatan pengelolaan potensi daerah;

5) peningkatan keamanan dan ketertiban; dan

6) peningkatan hubungan yang serasi antara pusat dan daerah.

Memang semestinya kehadiran daerah otonom baru itu demi kepentingan dan kesejahteraan masyarakat yang ada di daerah. Alasan dan tujuan utama dari masyarakat dalam pemekaran DOB Galela-Loloda yaitu pertama, GalelaLoloda (GALDA) merupakan daerah terluar yang berbatasan dengan negara lain, maka perlu dipikirkan dan dipertimbangkan untuk bisa menjadi Daerah Otonom Baru, kedua, Pemekaran daerah itu supaya masyarakat GalelaLoloda ingin lebih sejahtera, dan ketiga, ingin mayarakat Galela-Loloda lebih makmur yang selama ini kurang masyarakat rasakan.
Pembentukan DOB Galela-Loloda mendapat respon positif dari berbagai pihak, baik itu dari pemerintah Kabupaten Halmahera Utara, DPRD Kabupaten Halmahera Utara, Pemerintah provinsi Maluku Utara, DPRD Provinsi Maluku Utara, serta direspon juga dari DPD RI Provinsi Maluku Utara. DPD RI memiliki peran yang sangat penting dalam mendorong pemekaran suatu daerah menjadi Otonom Baru, begitu juga dalam Pembentukan DOB Galela-Loloda, DPD RI Provinsi Maluku Utara punya peran dan andil yang cukup besar untuk mendorong DOB Galela-Loloda menjadi Kabupaten Baru yang berotonom. Peran DPD RI Provinsi Maluku Utara dalam pembentukan atau pemekaran Daerah Otonom Baru Galela-Loloda yaitu aktif mendorong Galela-Loloda secepatnya bisa dimekarkan menjadi Daerah Otonom Baru. Setiap tahapan-tahapan dalam proses Pembentukan DOB Galela-Loloda, DPD RI Provinsi Maluku Utara selalu aktif dan ikut serta bersama-sama masyarakat dan pemerintah daerah.

Peran DPD RI Provinsi Maluku Utara pada tahap awal pembentukan DOB Galela-Loloda yakni menerima semua aspirasi masyarakat Galela-Loloda, aktif menindaklanjuti sesuai dengan desain besar rencana pembangunan DOB yang dikeluarkan oleh pemerintah. Pada tahap proses uji kelayakan DOB Galela-Loloda, peran DPD RI Provinsi Maluku Utara yakni melakukan kunjungan kerja untuk melihat:

1. Batas-batas wilayah Galela-Loloda,

2. Syarat fisik kewilayahan,

3. Jumlah penduduknya, dan

4. Potensi Daerah 
Tahap proses pembahasan di tingkat DPD RI dan DPR RI khususnya Komisi II, peran DPD RI Provinsi Maluku Utara yakni bersama-sama dengan DPD RI, DPR RI dan Pemerintah membahas DOB Galela-Loloda, menyampaikan semua hasil kajian yang telah dilakukan dan DPD RI Provinsi Maluku Utara menyatakan Galela-Loloda layak untuk dimekarkan menjadi Daerah Otonom Baru. Perkembangan terakhir sekarang menunggu sidang Paripurna DPR RI untuk pengesahan Galela-Loloda dapat dinyatakan sebagai kabupaten baru yang berotonom.

\section{KESIMPULAN}

1. DPD RI Provinsi Maluku Utara berperan aktif dalam mendorong pembentukan atau pemekaran Daerah Otonom Baru (DOB) Galela-Loloda menjadi kabupaten baru. Setiap tahapan-tahapan dalam proses Pembentukan DOB Galela-Loloda, DPD RI Provinsi Maluku Utara selalu aktif dan ikut serta bersama-sama masyarakat dan pemerintah daerah.

2. Peran DPD RI Provinsi Maluku Utara pada tahap awal pembentukan Daerah Otonom Baru (DOB) Galela-Loloda yakni menerima semua aspirasi masyarakat Galela-Loloda, aktif menindaklanjuti sesuai dengan desain besar rencana pembangunan Daerah Otonom Baru (DOB) yang dikeluarkan oleh pemerintah.

3. Pada tahap proses uji kelayakan Daerah Otonom Baru (DOB) Galela-Loloda, peran DPD RI Provinsi Maluku Utara yakni melakukan kunjungan kerja untuk melihat (a) Batas-batas wilayah GalelaLoloda, (b) Syarat fisik kewilayahan, (c) Jumlah penduduknya, dan Potensi Daerah.

4. Tahap proses pembahasan di tingkat DPD RI dan DPR RI khususnya Komisi II, peran DPD RI Provinsi Maluku Utara yakni bersama-sama dengan DPD RI, DPR RI dan Pemerintah membahas Daerah Otonom Baru (DOB) GalelaLoloda, menyampaikan semua hasil kajian yang telah dilakukan dan DPD RI Provinsi Maluku Utara menyatakan Galela-Loloda layak untuk dimekarkan menjadi Daerah Otonom Baru.

\section{DAFTAR PUSTAKA}

B LA SUHU, S IP, MA Abdul Gaffar Karim - 2011, PEMEKARAN DAERAH: PRO-KONTRA DAN KONSPIRASI (Studi Tentang Konfigurasi Elit dalam Pemekaran

Kabupaten Kepulauan Obi Halmahera Selatan-Maluku Utara), Universitas Gadjah Mada

Efriza dan Syafuan Rosi, Parlemen Indonesia Geliat Volksraad Hingga DPD Menembus Lorong Waktu Doloe, Kini, dan Nanti, Alfabeta CV, Bandung, cet kesatu, 2010.

Ibrahim AH, Supriatna Tjahja, 2019; Epistemologi Pemerintahan: Paradigma Manajemen, Birokrasi dan Kebijakan Publik. Penerbit UMMU Press, Ternate.

Eko Prasojo. Jorjoran Pembentukan Daerah: Instrumen Kepentingan Ekonomi 
Politik. Dalam Opini Jawa Pos, 2008.

Huda, Ni'matul. 2005. Hukum Tata

Negara Indonesia. Jakarta: PT Raja Grafindo.

J. Kaloh, 2007. Mencari Bentuk Otonomi

Daerah (Suatu Solusi dalam menjawab kebutuhan Lokal dan Tantangan Global) . PT Rineka Cipta, Jakarta.

Moleong J. Lexy, 2006; Metodologi Penelitian Kualitatif, Edisi Revisi. Penerbit PT. Remaja Rosdakarya, Bandung.

Soekanto,
Raja GrafindoPersada, Jakarta 1982.

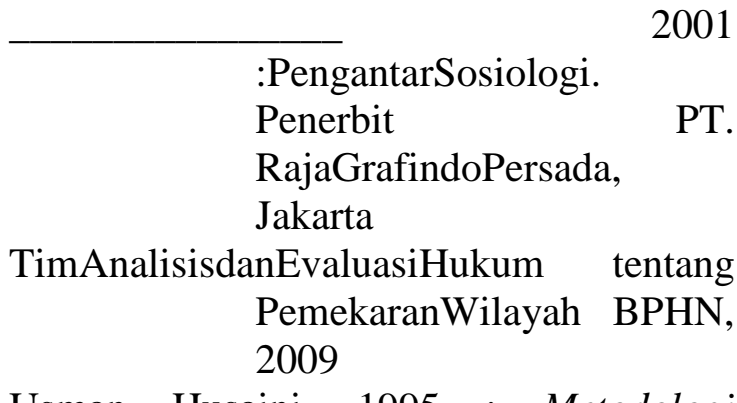

Usman Husaini, 1995 ; Metodologi Penelitian Sosial. Penerbit Bumi Aksara, Bandung.

Peratura Pemerintah (PP) Nomor 78 Tahun 2007 Tentang Tata Cara Pembentukan, Penghapusan, dan Penggabungan Daerah 